\title{
Disputed Election Results: A More Rigorous "Magic Number Test"
}

\section{Francis Hane ${ }^{\star}$ and Heather Emptage ${ }^{\star *}$}

The Gore v Bush ${ }^{1}$ disputed election case brought the questioning of the accuracy of election procedures into international news and the minds of electors worldwide. In addition to this notorious case, there have been a number of disputed election results in recent years each generating extensive public interest and forcing the judiciary into difficult and split decisions having wide ranging policy and constitutional implications. Elections are the pillar of democratic societies and in order for citizens and societies to have faith in their system of government, elections must be transparent, accurate and binding. In many nations, including Canada, the democratic process is enshrined in their constitution, regardless of whether it is written or unwritten, codified or not.

Section 3 of the Canadian Charter of Rights and Freedoms ${ }^{2}$ guarantees voting rights as follows: "[e]very citizen of Canada has the right to vote in an election of members of the House of Commons or of a legislative assembly and to be qualified for membership therein." This right is a fundamental right that is considered to be the foundation of our democratic process.

Following the 2011 federal election, a number of disputed election results in Canada have generated intense public interest ${ }^{3,4}$. In each one of these cases, the introduction of statistical evidence would have provided a quantitative measure of the probability that the challenger had actually won the election had improprieties not taken place. This brief article introduces a statistical test, novel to the jurisprudence, that deter- mines the probability that the challenger actually won the election and is, consistent with the language of the Supreme Court of Canada, a more realistic "magic number test".

\section{The Opitz Case}

In the fall of 2012, the Supreme Court of Canada released its decision in the Opitz $v$ Wrzesnewskyj case $^{6}$, allowing elected Member of Parliament Ted Opitz to keep his seat in the House of Commons. Due to perceived irregularities in the voting process, Borys Wrzesnewskyj, the defeated Liberal candidate in the riding of Etobicoke Center, wanted the court to annul the election in the hope of securing a win in an eventual by-election. The applicant Wrzesnewskyj was successful in convincing Mr. Justice Lederer of the Ontario Superior Court of Justice that due to irregularities in the handling of the election by Elections Canada, the results of the election should be annulled and a by-election held. Opitz appealed by right and in a split decision, the Supreme Court of Canada allowed the appeal.

The issue in Optiz was that at several polling stations during the 2011 Federal Election, administrative mistakes by Elections Canada created "voter irregularities" by either misplacing a number of voter registration certificates, or not ensuring that the registration certificates were signed resulting in possibly allowing people to vote who were not entitled to vote. In no way was any corruption or election fraud alleged. The number of "irregular" voter registration certifi- 
cates (79) exceeded the plurality of votes by which Opitz won (26) making it plausible, prima facie, that enough of these voters would have voted for Wrzesnewskyj to provide him with an election victory ${ }^{7}$. This formula for determining whether an election should be annulled was accepted by the Supreme Court of Canada in their decision which they refer to as the "magic number test".

\section{The Canada Elections Act ${ }^{9}$ allows:}

524. (1) Any elector who was eligible to vote in an electoral district, and any candidate in an electoral district, may, by application to a competent court, contest the election in that electoral district on the grounds that

(a) under section 65 the elected candidate was not eligible to be a candidate; or

(b) there were irregularities, fraud or corrupt or illegal practices that affected the result of the election.

The Act further provides the following remedy:

531. (2) After hearing the application, the court may dismiss it if the grounds referred to in paragraph $524(1)(a)$ or (b), as the case may be, are not established and, where they are established, shall declare the election null and void or may annul the election, respectively.

Mr. Justice Lederer of the Ontario Superior Court of Justice held the election to be null and void because there was an irregularity in the election because the margin of victory (26 votes) was less than the number of irregular certificates $(59 \text { certificates })^{10}$.

In their split (4-3), yet highly pragmatic decision, the Supreme Court of Canada adopted a substantive approach to the interpretation of the Canada Elections Act ${ }^{11}$ by drawing on the Charter, ${ }^{12}$ principle that the right to vote is an "enfranchising"13 right which citizens shall not be deprived of. The majority held that under the substantive approach, there must be a "breach of the statutory provision designed to establish the elector's entitlement to vote" 14 where someone who is not entitled to vote, did vote. The majority further voiced a warning that elections results should be overturned only in the rarest of circumstances because doing so would disenfranchise the vast majority of voters whose votes would be cast aside ${ }^{15}$.

In applying these principles to this case, the majority found, as a matter of fact, that the 59 votes annulled by Mr. Justice Lederer, should be restored bringing the plurality ${ }^{16}(26)$ to less than the number of disputed votes $(20)^{17}$. Given the urgency of the matter and that witness credibility was not a factor, the majority gave no deference to the application judge's findings of fact choosing rather to make a final order as opposed to returning the case to the Superior Court for a rehearing of the application. ${ }^{18}$

\section{The Supreme Court of Canada's "Magic Number Test"}

To settle these types of disputes, the Supreme Court of Canada adopted the following simple "magic number test" which was first proposed in Blanchard: ${ }^{19}$ if the number of votes in question is greater than the margin of victory, the court may annul the election results. ${ }^{20}$ Despite its simplicity, the "magic number test" is not the most rigorous test possible and is somewhat inconsistent with the ideal expressed by the majority in this case: that voting is an enfranchising act by the electorate and results must be annulled in only the rarest of circumstances. ${ }^{21}$ If a Court were to annul an election the voters who had cast their votes legitimately would be deprived of their right to vote. Even though the probability of a successful application of the "magic number test" by a losing candidate is quite rare, a more rigorous test would make the challenge and annulment of an election a near impossibility providing an even greater level of voter enfranchisement and consistency with general constitutional and Charter ${ }^{22}$ principles.

Using the test explained below, we calculated that the probability that Wrzesnewskyj could have won the election was $0.4 \%$; however, neither this nor any other statistical evidence was put on the record at the initial proceedings. The Supreme Court of Canada itself recognized this improbability. ${ }^{23}$ Perhaps had counsel for $\mathrm{Mr}$. Opitz introduced this statistical evidence at the 
application before Mr. Justice Lederer of the Superior Court, Mr. Opitz would not have had to appeal to the Supreme Court of Canada. The Court left open the possibility of an improved "magic number test" which is more reliable and would not compromise the secrecy of the ballot. $^{24}$

\section{The proposed more rigorous "magic number test":}

In statistics, this test is referred to as a "binomial distribution" 25 and is used to determine the probability of obtaining a given number of successes in a fixed number of trials. ${ }^{26}$ The binomial distribution is universally accepted by statisticians and is commonly used in science and industry for predicting events such as the number of patients who will have an adverse reaction to a drug or the probability of a sports team winning a series of games. We present this test as one which could be applied by counsel or the judiciary without expert testimony and which requires only a basic calculator $^{27}$ and a sheet of notepaper. Using this test, we demonstrate the probability that Wrzesnewskyj would have been found to have won the election. We further propose that this test could be used by future judges presiding in election applications to determine whether to annul the result of tight elections should irregularities, or even fraud, ${ }^{28}$ occur. The adoption of this test could be the ideal sought by the Supreme Court of Canada in the Opitz ${ }^{29}$ decision as its rigour would discourage and minimize needless election litigation.

The binomial distribution, which is thoroughly explained below, is expressed by the mathematical equation: ${ }^{30}$

$$
P=\sum_{0}^{x} \frac{n !}{(n-x) ! x !} p^{x} q^{n-x}
$$

Where $\mathrm{P}$ is the probability of a win by the challenger, and therefore that the irregularities affected the results of the election, $\mathrm{x}$ is the number of disputed votes, $\mathrm{n}$ is the plurality of victor $^{31}, p$ is the percentage of the vote that the loser obtained (expressed as a decimal ${ }^{32}$ ) and $\mathrm{q}$ is 1-p. ! is the factorial operator ${ }^{33}$ and multiplies all numbers up to $\mathrm{x}$. The $\Sigma$ symbol is the summation symbol: it means add up all the values from 0 to $\mathrm{x}^{34}$.

In order to demonstrate how this equation would work, we present the following hypothetical example:

In our hypothetical example, following the election, a scrutineer for the Liberal candidate Selkoe approaches the returning officer with a complaint that election officials did not allow 55 people to vote because they did not have identification. The potential voters were not given the option of returning with a person to vouch for them as allowed in the Canada Elections Act. ${ }^{35}$ The Liberal Party wishes to contest the results of the election and files an application with the Superior Court of Justice. Using the existing "magic number test" which was used in the Opitz case, which shows that the margin of victory (27 votes) is less than the number of disputed votes (55), there is a strong possibility that under the existing "magic number test", the election result would be annulled and a new by election ordered.

Table 1 shows the results of a sample election between 3 parties:

\begin{tabular}{|c|c|c|}
\hline $\begin{array}{c}\text { Candidate for } \\
\text { Sample Riding }\end{array}$ & $\begin{array}{c}\text { Votes } \\
\text { Obtained } \\
\text { In Election } \\
\text { Results }\end{array}$ & \% of votes \\
\hline Glabe (NDP) & 58286 & 42.3 \\
\hline Selkoe (Lib) & 58259 & 42.3 \\
\hline Teplow (Con) & 21245 & 15.4 \\
\hline TOTAL & $\mathbf{1 3 7 7 9 0}$ & $\mathbf{1 0 0 \%}$ \\
\hline Disputed & 55 & \\
\hline
\end{tabular}

Table 1 - sample election results

In our example, as shown in table 1 , out of 55 disputed votes, challenger Selkoe needs 27 of these votes to win. Since Glabe achieved $42.3 \%$ of the vote, the expected number of votes he would have received from the 55 disputed votes is $42.3 \%$ of 55, or 23 votes. However, we are more con- 
cerned with the probability "affected the results of the election" and seek to determine the probability that Selkoe actually received 27 or more of these 55 disputed votes.

In this example, ${ }^{36} \mathrm{p}=0.423$ (percentage of the vote expressed as a decimal, $\mathrm{n}=55$ (55 disputed votes), $\mathrm{x}=27$ (plurality of the win), $\mathrm{p}=0.423$, $\mathrm{q}=0.577$.

$$
\begin{aligned}
P= & \sum_{0}^{27} \frac{55 !}{(55-x) ! x !} 0.423^{x} 0.577^{(55-x)} \\
= & \frac{55 !}{(55-1) ! 1 !} 0.423^{1} 0.577^{(55-1)} \\
& +\frac{55 !}{(55-2) ! 2 !} 0.423^{2} 0.577^{(55-2)} \\
& +\ldots+\frac{55 !}{(55-27) ! 27 !} 0.423^{27} 0.577^{(55-27)} \\
P & =0.875
\end{aligned}
$$

Stating this result in plain English, the probability that Glabe did indeed win this election is $87.5 \%$. Conversely, the probability that Selkoe won this election is $12.5 \%{ }^{37}$ : therefore, the irregularities had a $12.5 \%$ chance of affecting the outcome of the election.

Applying this 'magic number test' to the $O p i t z^{38}$ case is slightly more difficult. Instead of voters who did not get to vote, there were 79 voters who may have not been eligible to vote. The plurality was 26 for Opitz. In this case, the votes tabulated are listed in Table 2, below. ${ }^{39}$

To be declared the winner, Wrzesnewskij needed Opitz to lose 48 votes while only losing 22 votes himself. Had the loss of votes been distributed as expected, Opitz would have lost 22 votes. $^{40}$ In this case, $\mathrm{n}=79$ (79 disputed votes), $\mathrm{x}=48$ (number of votes Opitz needed to lose to have Wrzesnewskyj to be declared the winner), $\mathrm{p}=0.465, \mathrm{q}=0.535 .{ }^{41}$ Applying these numbers to the binomial distribution equation given above indicates that the probability that Opitz obtained more votes than Wrzesnewskyj is $99.6 \%$. Conversely, the probability that Wrzesnewskyj won the election is $0.4 \%$. Had the Superior Court applied the binomial distribution equation as described in this article it would be apparent that,

\begin{tabular}{|c|c|c|c|}
\hline Candidate in Sample Riding & $\begin{array}{c}\text { Votes Obtained } \\
\text { In Election Results }\end{array}$ & \% of votes & $\begin{array}{c}\text { Votes to Win after } \\
\text { Disputed Votes } \\
\text { Counted }\end{array}$ \\
\hline Opitz (Con) & $\mathbf{6 1 6 4 4}$ & 46.52 & 61594 \\
\hline Wrzesnewskyi (Lib) & 61618 & 46.50 & $\mathbf{6 1 5 9 5}$ \\
\hline Rivero (NDP) & 7735 & 5.84 & 7730 \\
\hline Zoricic (Grn) & 1377 & 1.03 & 1376 \\
\hline Thompson (MLP) & 149 & 0.11 & $\mathbf{1 3 2 4 4 4}$ \\
\hline TOTAL & $\mathbf{1 3 2 5 2 3}$ & & \\
\hline Disputed & 79 & & \\
\hline
\end{tabular}

Table 2 - Votes cast in Etobicoke - Centre in the 2011 Federal election 
despite 79 irregular voters, there was only a very small probability that Wrzesnewskyj could have won the election had all the disputed votes been voided. This result would have negated s. 524 (1) (b) of the Canada Elections Act, that "irregularities... affected the result of the election" ${ }^{\prime \prime 2}$ as the Court could have been easily satisfied that these irregularities did not, in fact, affect the result.

It is worth noting that this test only returns a probability of the challenger actually having won the election, not a binary "affects or doesn't affect" result. The result of this outcome is that the court may annul the election if the court feels the result affected the remedy; it is solely a discretionary remedy. So what is an appropriate probability for a finding of affecting an election result? While generally one would presume that a court must be satisfied on a balance of probabilities test, this may not be entirely acceptable given the importance of election accuracy to our system of government and constitutional principles. This probability would have to be determined through future jurisprudence, but $51 \%$ leaves an insufficient margin for the possibility that the election was affected by irregularities. Conversely $99 \%$ certainty is likely too high a certainty to maintain the Supreme Court of Canada's objective of ensuring that votes cast remain standing; however, a $99 \%$ standard is still more rigorous and consistent with constitutional Charter $^{43}$ values than the existing "magic number test" as applied in Opitz. ${ }^{44}$

To further simplify matters a chart is presented below which indicates the probability of an election outcome being affected as a function of certainty. The lower the popular vote by the loser, the greater the number of votes above the expected number needed for the winner to prove that the disputed votes did not affect the election.

For example, Smith, the loser, challenges Walsh because of 50 disputed ballots. Both candidates obtained approximately $40 \%$ of the popular vote, but Walsh obtained 8 more votes than Smith. Of these 50 disputed ballots, Smith requires a minimum of 26 of the possible 50 votes with the remainder of the votes going to Walsh in order for Smith to have won the election. If the 50 disputed voters voted consistent with the election results, Smith would have received 20 of the 50 disputed votes. The number of votes needed (26) votes needed is $30 \%$ higher than the expected number of votes (20). Referring to table 3 , we can cross reference the loser's percentage of

\begin{tabular}{|c|c|c|c|c|}
\hline & \multicolumn{4}{|c|}{ Percentage Certainty that Election Results Were Not Affected } \\
\hline $\begin{array}{c}\text { Loser's percentage of } \\
\text { popular vote }\end{array}$ & $75 \%$ & $90 \%$ & $95 \%$ & $99 \%$ \\
\hline $30 \%$ & $20 \%$ & $33 \%$ & $40 \%$ & $53 \%$ \\
\hline $35 \%$ & $14 \%$ & $26 \%$ & $37 \%$ & $47 \%$ \\
\hline $40 \%$ & $15 \%$ & $25 \%$ & $30 \%$ & $45 \%$ \\
\hline $45 \%$ & $11 \%$ & $22 \%$ & $29 \%$ & $38 \%$ \\
\hline $48 \%$ & $13 \%$ & $21 \%$ & $25 \%$ & $38 \%$ \\
\hline $50 \%$ & $12 \%$ & $20 \%$ & $24 \%$ & $36 \%$ \\
\hline
\end{tabular}

Table 3 - Percentage above expected number of votes for challenger to prove "affected" as a function of percent certainty ${ }^{45}$. Arrows serve to direct the direction of reading this chart consistent with the example below. 
the popular vote in the first column (40\%) with the percentage above the expected vote needed to win (30\%). Referring to the first column, we can be $95 \%$ certain than these disputed ballots did not affect the outcome of the election. Or, in other words, there is only a $5 \%$ probability that the loser actually won this election had there been no irregularities. In another brief example based on the example above, if the expected number of votes needed was only $15 \%$ above what would be expected, there would only be a $75 \%$ probability that the irregularities did not affect the election result.

In general, to be $90 \%$ certain that irregularities did affect the election results, the margin of victory must be within $20-33 \%$ of the disputed election votes.

While this test accurately predicts to probability of a loser to have actually won the election, it bears repeating that the threshold at which the calculated probability "affected the outcome of the election" is subject to judicial interpretation. If this threshold is $50 \%$ or $90 \%$ or $95 \%$, it will have to be determined over time through jurisprudence.

The test presented in this article is a simple method for any counsel or member of the judiciary involved in disputed election litigation to apply. It is consistent with constitutional and Charter ${ }^{46}$ values and the principle of the rarity of election annulments elucidated by the Supreme Court of Canada in Opitz. ${ }^{47}$ We submit that the adoption of this test by the courts will promote the democratic process and minimize election litigation by ensuring that votes which are legitimately cast remain valid.

\section{Endnotes}

* Francis Hane, B.Sc. (Embry-Riddle A.U.), M.Sc. (Waterloo), Ph.D. (Waterloo) is a post-doctoral fellow at the University of Waterloo.

** Heather Emptage, H.BA. (WLU), LL.B. (Laval), J.D./LL.M. (Montréal) is a staff lawyer at Legal Aid Ontario.

1 Gore v Bush (2000) 531 US 98
2 Canadian Charter of Rights and Freedoms, Part I of the Constitution Act, 1982, being Schedule B to the Canada Act 1982 (UK), 1982, c 11.

3 Opitzv Wrzesnewskyj (2012) SCC 55.

4 McEwing v Attorney General of Canada (2013) FC 525.

5 Wrzesnewskyj v Attorney General (Canada), 2012 ONSC 2873, at para 71.

6 Supra note 3.

7 Wrzesnewskyj needed Opitz to lose 48 votes while only losing 23 himself to be declared the winner.

8 Supra note 3.

9 Canada Elections Act SC 2000 [the Act].

10 Supra note 5 at para 154.

11 Supra note 9.

12 Supra note 2.

13 Supra note 6 at para 50.

14 Supra note 5 at para 58.

15 Supra note 3 at para 66.

16 The plurality is the margin of victory or number of votes the winner won by.

17 Supra note 3 at para 78.

18 Ibid at para 81.

19 Blanchard v Cole, [1950] 4 D.L.R. 316 (N.S.S.C.).

20 Supra note 3 at para 73.

21 Ibid at para 3.

22 Supra note 2.

23 Supra note 3 at para 72.

24 Ibid at para 73.

25 Box, Hunter and Hunter (1978). Statistics for experimenters. Wiley.

26 For example, rolling a dice 10 times, what is the probability of rolling three 6 's.

27 Quantum of damages is calculated the same wayby counsel or a judge with a calculator.

28 While fraud is a considerably different case than an inadvertent mistake by Elections Canada, a court would have to decide whether a different standard should be applied to take into account punitive measures against a winning, yet corrupt candidate.

29 Supra note 3 at para 73.

30 The authors understand that this expression may be intimidating, but with a few minutes of study will likely become obvious to anyone who completed mathematics to the university entrance level.

31 The plurality is the number of votes that a candidate won by

32 A percentage of $42.9 \%$ is $\mathrm{p}=0.429, \mathrm{q}=(1-$ $0.429)=0.571$

33 For example 5! =1 × 2 × 3 × 4 × $5=120$.

34 All the numbers must be added up because each calculation yields the probability that the loser 
obtained $\mathrm{x}$ number of votes. We want to calculate the probability that the candidate got any number of votes exceeding the plurality of victory.

35 Supra note 9 at s.143.3.

36 Notice how the summation symbol adds up all terms from 1 to 27 . For brevity the terms for $n=3$ to $n=26$ are omitted from this example. Each term calculates the probability of winning by that number of votes. Adding all these individual probabilities calculates the probability of winning.

$37-1-0.875=0.125=12.5 \%$

38 Supra note 3.

39 Elections Canada election results obtained from Elections Canada website http://www.elections.ca/ scripts/ovr2011/default.html downloaded January 4,2013

4079 votes $x 46.52 \%$

$41 \quad 1-0.465=0.535$

42 Canada Elections Act SC 2000

43 Supra note 2.

44 Supra note 3.

45 This table was tabulated using the equation listed above and serves as a quick reference as opposed to having to calculate the probability mathematically.

46 Supra note 2.

47 Supra note 3 at paras 66-67. 
